Ankara Üniversitesi Türk İnkılâp Tarihi Enstitüsü Atatürk Yolu Dergisi

S 37-38, Mayts-Kasim 2006, s. 1-14

\title{
Hamdullah Suphi'nin Kaleminden 1933 Yılında Romanya'da Komünist Hareket
}

\author{
Yrd. Doç. Dr. Yonca ANZERLİŎLLU*
}

ÖZET

Türk Ocakları'nın kapanmasının ardından Hamdullah Suphi Tanriöver 19311944 yılları arasında Romanya'da Büyükelçilik yapmıştır. Görevi süresince Romanya'nın iç siyasetine yönelik olarak Ankara'ya gönderdiği raporlar arasında kapsamlı olması ile dikkati çekenlerden birisi 1933 yılında Romanya'da Komünist örgütlenme hakkında hazırlamış olduğu rapordur. Bu çalışmada Türkiye Büyükelçisinin gözüyle Romanya'daki Komünist teşkilatlanma ve bu bağlamda anılan yılda Romanya iç siyasetinden bir kesit verilmeye çalışılmaktadır.

Anahtar Kelimeler: Hamdullah Suphi, Romanya, Komünizm, Komünist Örgütlenme.

\section{ABSTRACT}

After closing the Turkish Society, Hamdullah Suphi Tanriöver was appointed as Bucharest Ambassador in 1931. Untill the end of his mission in 1944, he paid a great attention to the internal policy of Romania. Some time he wrote detailed reports to Ankara about the developments in mentioned country and one of these reports is about the Communist organizations and their activities performed in 1933. In this study it is tried to explain these organisations and their activities from the perspective of Turkish Ambassador and in this manner, to give also a political panorama of Romanian internal situation in 1933.

Key Words: Romania, Hamdullah Suphi, Communism, Communist Organization.

\footnotetext{
•Hacettepe Üniversitesi Atatürk İlkeleri ve İnkılâp Tarihi Enstitüsü Öğretim Üyesi.
} 


\section{GíRIŞ}

I. Dünya Savaşı sonunda Avusturya'dan Bukovina'yı, Macaristan'dan Banat'1, Rusya'dan Besarabya'y1 ve Bulgaristan'dan da Dobruca'nın bir kısmını alan Romanya, topraklarını genişleten statükocu bir ülke durumundadir.

Öncelikle yakın çevresine bakılacak olursa, Romanya'nın savaş sonrasında komşularından aldığı topraklar düşünüldüğünde genişleyen sınırları ile bir tehlike çemberinin içinde bulunduğu görülmektedir. Böyle bir ortamda güvenlik tedbirlerini Batıya, özellikle de Fransa'ya yakınlaşmakta arayan Romanya, Macaristan'ın revizyonist siyasetine karşı tedbir amacıyla Tuna ve Balkanlar için büyük öneme sahip olan Küçük Antant ${ }^{1}$ oluşumuna dahil olmuştur. Bunun dışında 1921 ve 1926 yıllarında Rusya'ya karşı Polonya ile, yine 1921'de Bulgaristan'a karşı Yugoslavya ile, 1926 yılında da Fransa ile ittifak imzalayarak var olan statükoyu korumayı hedeflemiştir ${ }^{2}$. 1934 yılında Romanya,Yugoslavya, Yunanistan ve Türkiye arasında imzalanan Balkan Antantı da, Romanya açısından bakıldığında, Bulgar tehlikesine karşı önemli bir tedbir olacaktır.

Balkan Antant'ını imzalayan ülkelerden Türkiye ile Romanya'nın diplomatik manada ikili ilişkilerinin başlangıç tarihi I. Dünya Savaşı yıllarına rastlamaktadır ${ }^{3}$. Savaşta Osmanlı müttefiki Almanya karşısında yer alan Romanya ile Osmanlı'nın ilişkisi kesilecektir. Türk Milli Mücadele sürecinde de bu şekilde devam etmiş olan ikili ilişkiler ancak Türkiye Cumhuriyeti'nin ilanından birkaç ay önce başlamıştır. Bu başlangıç ile Cevat Bey Bükreş'e Türk temsilcisi, Petre Aurelian da Türkiye'ye Yüksek Romen Komiseri olarak tayin olmuştur. Lozan Barış görüşmeleri sırasında Romanya özellikle kapitülasyonların kaldırılması konusunda Türkiye'yi desteklerken, ülke ticareti için oldukça önemli olan boğazların durumu konusunda da yeni bir düzenleme talebinde bulunmuştur. Antlaşmanın imzalanması sonrasında ise 6 Haziran 1924 tarihinde Ankara ve Bükreş'te karşılıklı elçilikler açılmıştır.

Yeni Türk elçisi Hüseyin Ragıb Baydur ile başlayan süreçle Türk Romen dostluğu giderek samimi bir havaya girmiştir. 1929 yılında TürkRomen ticaret ve ekonomik anlașmalarının imzasını 1930 yılında mezarlıkların muhafazası ve bakımı ile ilgili Türk-Romen anlaşması takip etmiştir. Hüseyin Ragıb Efendiden sonra Sabri Toprak'ın elçiliği sırasında da iki ülke ilişkileri gelişmeye devam etmiştir (1Nisan 1929-30 Nisan $1930)^{4}$.

' Küçük Antant ile ilgili detaylı bilgi için bkz.: Fahir Armaoğlu, Siyasi Tarih, C.1-2, İstanbul, t.y., s.188-190.

${ }^{2}$ Armaoğlu, a.g.e., s. 185.

${ }^{3}$ Bundan önce Osmanlı idaresi ile Eflak ve Boğdan-Romen Prenslikleri- arasındaki ilişki ve Romanya'nın bağımsızlı̆̆ı ile ilgili olarak bkz. Kemal Karpat, Balkanlar'da Osmanl Mirası ve Ulusçuluk, Ankara, 2004, ss.357-366.

${ }^{4}$ Mihail Guboğlu,“Atatürk'ün Cumhurbaşkanlığı Döneminden II. Dünya Savaşı'na Kadar Türk-Romen Ilişkileri(1923-1944)”, Belleten, C.XLVII, sa.188, Ekim 1983, 1047-1051 
1930'lu yıllar Balkan Antantı ${ }^{5}$ hazırlıklarının yapıldığı yıllardır. Bu yıllarda, 1931'de Bükreş elçiliği görevine getirilen kişi 1944 yılına kadar Türk-Romen ilişkilerinin gelişmesinde ciddi mesafelerin kat edilmesinde büyük emeği geçecek Hamdullah Suphi Tanrı̈ver ${ }^{6}$ olacaktır.

Göreve başladığı andan itibaren Romanya'da gerek kraliyet gerekse hükümet çevrelerinde saygın bir yer edinen Hamdullah Suphi için Romanya topraklarında yaşayan Müslüman ve Hıristiyan Türkler özel ilgi alanını oluşturacak ve Romanya Türklerinin durumunun düzeltilmesi için elinden gelen çabayı sarf edecektir ${ }^{7}$. Bunda büyük başarı elde eden Hamdullah Suphi elçilik görevi süresince Romanya iç siyasetini yakından takip etmiştir. Bu bağlamda ülkede yaşanan gelişmeler ile ilgili Türkiye'ye gönderdiği raporlar o günün Romanya'sının siyasi ekonomik ve kültürel portesini ortaya koymada birinci derecede öneme sahiptir.

1930'lu yılların Romanya'sı siyasi istikrarsızlığın hat safhaya ulaştığı yıllardır denilebilir. Böyle bir ortamda Romanya'da elçilik yapan Hamdullah Suphi'nin Türkiye'ye gönderdiği raporlardan da durumu tespit etmek mümkündür. Bu raporlar içinde dikkat çekici olanlarından birisi Romanya'da 1930'lu yılların başında komünizmin bir tehlike olarak algılanması karşısında "komünizmin Türk vatanına pek yakın olan bu köşede hakiki mahiyetini tespit etmek elzemdir" fikriyle hazırlanan ve "Romanya'daki Komünist fikir hazırlı̆̆l(nın) nasıl cereyan ettiğini" detaylarıyla anlatan rapordur. Bu çalışmada Hamdullah Suphi'nin, kendi deyimiyle bu Komünist cereyanı nasıl değerlendirdiği ve bu bağlamda Romanya'nın genel siyasi durumunu nasıl gördüğü ele alınarak incelenmeye çalışılacak ve dolayısıyla anılan yılda Romanya siyasi tarihinden bir kesit verilmeye çalışılacaktır.

Raporu incelemeye geçmeden önce 1930 yılına gelinceye kadar Romanya'nın siyasi durumunu kısaca özetlemekte fayda vardır.

${ }^{5}$ Konu ile ilgili detaylı bilgi için bkz. Mehmet Gönlübol, Cem Sar, Olaylarla Türk Dış Politikası (1919-1973), Ankara, 1982, s. 103-111; Fahir Armaoğlu, 20. Yüzyll Siyasi Tarihi, Îstanbul, t.y., s.337.

${ }^{6}$ Hamdullah Suphi 1885 tarihinde İstanbul'da dünyaya gelmiştir. Köklü bir aileye sahip olan Hamdullah Suphi'inin babası çeşitli bakanlıklarda bulunmuş olan Abdullatif Suphi Paşa, dedesi Tanzimat dönemi vezirlerinden Abdurrahman Sami Paşa, amcası yine Tanzimat döneminin ünlü edebiyatçılarından Sami Paşazade Sezai Bey'dir.1904 yılında Galatasaray Sultanisini bitirdikten sonra Tütün İnhisarı Merkez İdaresi Tercüme Kaleminde memur olarak hayata atılan Hamdullah Suphi, 1908'de öğretmenlik yapmaya başlamıştır. 1912'de kurulan Türk Ocakları ile ismi özdeşleşen Hamdullah Suphi Ocak kapatılana kadar başkan olarak kalmıștır. Son Osmanlı Mebusan Meclisi'nde Saruhan ve Antalya mebusu olan Hamdullah Suphi 23 Nisan 1920 tarihinde Anadolu'da yeni bir başlangıca imza atan Büyük Millet Meclisi'nde de Antalya milletvekili olmuştur. Ünlü bir hatip olan ve Maarif Vekilliğine iki kez atanan Hamdullah Suphi 1931'de Bükreș'e birinci sınıf elçi olarak atanmış, daha sonra Büyük Elçiliğe terfi etmiştir. Türkiye'ye döndükten sonra siyasete devam eden Hamdullah Suphi 1966 yılında hayatını kaybetmiştir.Bkz. Adil Dağıstan, "Hamdullah Suphi'nin Romanya Büyükelçiliği ve Gagauz Türkleri”, Atatürk Araștırma Merkezi Dergisi, c.XVIII, Kasım 2002, sa.54; Fethi Tevetoğlu, Hamdullah Suphi Tanrı̈̈ver, Ankara, 1986.

${ }^{7}$ Konu ile ilgili olarak bkz. Tevetoğlu, a.g.e.; Dağıstan, a.g.m.,; Anzerlioğlu, a.g.m. 


\section{0-1930'lu Yullarda Romanya'da Siyasi Durum}

I. Dünya Savaşı sonunda büyük toprak sahiplerinin çıkarları doğrultusunda hareket eden ve Alman yanlısı bir siyaset uygulayan Muhafazakar Partinin zayıflamasıyla ülkede yönetim Julius Maniu'nun liderliğindeki Köylü Partisine geçmiştir. Bu iktidar döneminin en çarpıcı özelliği yapılan toprak reformu ile köylüye toprak dağıtılmasıdır. 1922-1928 arası özel teşebbüsü savunan Liberal Partinin iktidarda olduğu dönemde, 1927 y1lında Kral Ferdinand ölmüş ve 1928 seçiminde Milli Köylü Partisi ciddi bir oy farkıyla tekrar iktidara gelmiștir. Ancak yeni hükümet özellikle tarım sektörünün sorunlarına çözüm getirememiş ve 1930 Ekim'inde istifa etmek zorunda kalmıştır. Bu arada daha önce Fransa'ya sürgüne gönderilen Kral Ferdinand'ın oğlu II. Carol, ülkeye dönmüş ve Romanya'nın yeni Kralı olarak tahtına oturmuştur ${ }^{8}$. Bundan sonra ise Köylü Partisi lideri Maniu kendisini destekleyeceğini düșündüğü Kral tarafından yönetimden ayrılmaya zorlanmıştır. Kral, karakterinin ülke siyasetine olumsuz yansıdığı bu yıllarda sahip olduğu hırs ve kurnazlıkla parti içi ve partiler arası çekişmeleri de kullanarak kısa sürede ülke yönetimini ele geçirmiştir. Milli Köylü Partisi lideri Prof. Iorga'nın etkisiz hale getirilmesini Maniu ile arası açık olan Köylü Partisi'nin liderlerinden Vaida'nın başbakan atanması takip etmiştir. Bu süreç sonunda da parti ikiye bölünmüştür. Aynı taktik Liberaller için de uygulanmıştır. Tatarescu, 1933 Aralık ayında hükümet kurmuş ve tam olarak dört yıl boyunca iktidarda kalmışsa da parti içinde görüş ayrılıkları ortaya çıkmıştır'.

Yine bu süreçte Avrupa'daki Nazizm ve Faşizm akımlarının güçlenmesi Romanya'da da etkisini göstermiştir. 1930'lu yıllarda Romanya faşizminin Führer'i olarak bilinen Corneliu Zelea Codreanu liderliğinde Demir Muhafizlar $^{10}$ adıyla kurulan teşkilat kanalıyla bir Slav çemberi içinde bulunan Romanya'da milliyetçilik güçlenmiştir. Burada şunu da belirmek gerekir ki ülkede var olan Musevi karşıtlığının yükselen milliyetçiliğe etkisi de yadsınamayacak kadar önemlidir.

Kral II. Carol, Demir Muhafızların gücüne dayanarak kısa sürede ülkede monarşik bir diktatörlük tesis etmeyi başaracaktır. Ancak 1938 yılı başlarına gelindiğinde kendisi için tehlike oluşturmaya başlayan bu teşkilatı da kapatarak tam anlamıyla monarşik bir diktatörlüğe yönelecektir. Böyle bir ortamda 1921 yılında kurulduğundan beri fazla taraftar bulamayan ve küçük bir parti olarak kalan Romanya Komünist Partisi için aslında değişen fazla bir şey olmayacaktır. Belirtildiği gibi parti kurulduğu andan itibaren liderlik ve üyelik bağlamında özellikle azınlıklara bağlı kalacaktır. Partinin bu

\footnotetext{
${ }^{8} \mathrm{Kral}$ Carol'un sürgün edilmesi ve ülkeye dönüşü ve tahta oturması ile ilgili olarak bkz. Larry L. Watts, Romanian Cassandra, Ion Antonescu and The Struggle for Reform, 1916-1941, New York 1993, 107-127.

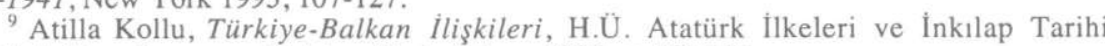
Enstitüsü, Yayınlanmamıs Doktora Tezi, Ankara, 1996, ss.168-175.

${ }^{10}$ A History of Romania, (ed.) Kurt Treptow, Iasi, 1996, s. 427; Stephan Fisher -Galati, Twentieth Century Romania, New York,1970, s.37.
} 
durumunda ilk zamanlarda takip ettiği siyasetin etkisi önemli bir yere sahiptir. Comintern'in milli egemenlik ve milli sınırları anakronizm olarak değerlendirmesi ve bu iki unsurun devrim ve uluslararası dayanışma ile ortadan kaldırılması gerektiği fikrinden hareketle Romanya Komünist Partisi, Beserabya'nın Sovyetler Birliği'ne bırakılması gerektiğini dile getirecektir. Ancak, bu görüşü ülke içinde ciddi bir tepki ile karşılanacak ve doğrudan bir ihanet olarak değerlendirilecektir. Bundan sonra ise Komünist Partisi II. Dünya Savaşına kadar, Gilberg'in deyimiyle, kendisini bir getto içinde bulacaktır ${ }^{11}$.

Her ne kadar Gilberg, Romanya Komünist Partisi'nin bir getto içinde olduğunu belirtse de o dönemde ülke içindeki Komünist teşkilatlanmanın özellikle yönetim kademesinde dikkate alınan, göz önünde bulundurulan bir tehdit olduğu ve bunun yanında ülkede bulunan yabancı temsilciliklerden Türkiye Cumhuriyeti Büyükelçiliğinin konuya karşı hassasiyet gösterdiği aşağıda yer verilen bilgilerden anlaşılmaktadır.

\section{Mart 1933 Tarihli Bükreş Türk Büyük Elçiliği Raporunda} Romanya'da Komünizm

I. Dünya Savaşı sonrasındaki iç siyaseti yukarıda kısaca özetlenen Romanya'da, Türkiye Cumhuriyeti Büyük Elçiliği görevini yürüten Hamdullah Suphi Tanrı̈̈ver görev yaptı̆̆ 1 süre içinde Türkiye'ye çeşitli konularda kapsamlı raporlar göndermiştir ${ }^{12}$. İşte bunlardan birisi de ülkenin karışık siyasi yapısı içinde özellikle hükümet çevrelerinde tehlike olarak algılanan Komünist teşkilatlanma konusunda Türk Dış İşlerine sunulmak üzere hazırlamış olduğu 129/56 ve 4 Mart 1933 tarihli rapordur.

Hazırladığı bu rapora: "Romanya'da ve Yugoslavya'da dahili vaziyetin vahametini inkişafa doğru seyrinden menedecek bir tedbir göze görünmüyor, bunun için her iki tarafın endişe ettiğ $i$ harici harp tehlikesi baş göstermeden evvel muhtemeldir ki dahili tehlikeler, bilhassa Romanya'da istikrarsızlık, hükümetsizlik şeklinde bir vahamet alacaktır"13 yorumu ile başlayan Büyük Elçi adı geçen iki ülkede, dışarıda meydana gelebilecek bir savaş halinden önce, özellikle de Romanya'da, ülke içinde bazı tehlikelerin baş gösterebileceğinin altını çizmektedir. Bu bağlamda, 1933 yılı Şubat ayının ilk günlerinde Romanya'da Vaida hükümetinin birden bire ortaya çıkan işçi isyanları karşısında örfi idare ilanına mecbur kaldığını belirtmekte ve başta saray çevresi olmak üzere ülkede sayıları 23'e ulaşan siyasi partilerle tüm teşkilatların perişan bir halde olduğuna vurgu yapmaktadır. Ayrıca, siyasi yapının bu durumu karşısında halkın tavrının ne olduğu ile ilgili olarak da

$"$ Trond Gilberg, Nationalism and Communism in Romania, The Rise and Fall of Ceausescu's Personal Dictatorship, Oxford,1990, 43-44.

${ }^{12}$ Romanya'da yaşayan Müslüman ve özellikle Hıristiyan Türk azınlıklar ve onların durumunun düzeltilmesi yönünde Hamdullah Suphi'nin gerçekleştirdiği faaliyetlerin detaylı biçimde anlatıldığı rapor bunlardan en dikkat çekici olanlarından birisidir. Rapor, Başbakanlık Cumhuriyet Arşivi'nde 030.10.246.666.30 no ile kayıtlıdır. Ayrıca bkz. Yonca Anzerlioğlu, "Bükreş Büyükelçisi Hamdullah Suphi ve Gagauz Türkleri”, Bilig, Güz 2006.

${ }_{13}^{3}$ Başbakanlık Cumhuriyet Arşivi, 0301024666717, s.2 
"halkın ne güvendiği bir zümre ne de inandığı bir kuvvetin" olmadığının altını çizmektedir ${ }^{14}$.

Ülkede var olan parlamenter yapı yanında kraliyet ailesinin devam ediyor olmasının da siyasi çevrelerde huzursuzluk yarattığı anlaşılmaktadır. Bu konuda Çiftçi Partisi başkanı Dr. Lupu'nun Millet Meclisinde meclis başkanlığından ihtar almasına sebep olan bir konuşmasını Hamdullah Suphi, "çok manal müessir ve yüksek derecede medeni cesarete delalet" eden bir konuşma olarak değerlendirmekte ve Dr. Lupu'nun, Avrupa'da hükümdar idaresinde yaşayan ülke sayısının azalmakta olup mevcut olanların da meşrutiyet esaslarına tam anlamıyla uydukları oranda kendilerini muhafaza edebildiklerine, Kuzey ve Güney Amerika'nın hiçbir yerinde kraliyete benzer bir idarenin var olmadığına ve İngiltere, Danimarka, Norveç ve İsveç dışında kraliyet ailesinin olduğu kaç ülke kaldığına şiddetle vurgu yaptığını belirtmektedir. Ayrıca Lupu'nun meclis başkanına yönelik olarak "Reis efendi cidden garip bir usul takip ediyoruz Biz herkesin bildiği(ni) bilmek istemeyen kimseleriz. Bu fikirleri bütün memleket söylüyor. Acaba memleketi temsil eden Meclis, milletin söylediğini söylemekten memnumudur?"'s sözlerine yer veren Hamdullah Suphi, ülke içinde yönetimde etkin olmaya çalışan saraya karşı ciddi bir tepkinin varlığına dikkat çekmeye çalışmaktadır.

Ülkede önce üniversite hocaları ardından da işçi isyanlarının ortaya çıkması, hükümetin kadro daraltması ve bütçede aylıklar üzerinde tenzilata gitmesi var olan bu infiali artırmıştır. Hükümet bu durum karşısında basın aracılığı ile resmi bir beyanname yayınlama gereği duymuştur. Hamdullah Suphi, hükümetin yayınladığı bu beyannamenin birkaç cümlesine, durumdan duyulan korkuyu yansıtması açısından, raporunda yer vermeyi uygun görmüştür. Beyanname "Romanyalılar!" hitabıyla başlamakta ve şöyle devam etmektedir: "Büyük bir tehlike memleketi tehdit ediyor. Cebr ile, anarşi ile onun inhilal etmesine teşebbüs edilmiştir. Gizli Komünist teşkilatı șiddet vasıtaları kullanarak devlet nizamını yıkmaya çalışmaktadır. Bu maksadın elde edilmesi için memleketin bir çok noktalarında iğtişaş hareketleri vücuda getirilmiștir. Diğer taraftan bazı anasır yaptıklarının farkında olmaksızın bu hükümeti yıkma teşebbüsüne yardım etmekte ve irtikap ettikleri cebr ve şiddet fiiller ile daha büyük felaketlerin gelmesine müsait bir bozgun havası hazırlamaktadırlar". Tüm bu duruma bağlı olarak hükümetin bazı noktalarda örfi idare kararı almaya mecbur olduğuna değinilen beyannamenin asıl dikkat çeken kısmının ise üniversite gençlerine hitabeden cümleleri olduğuna değinen Hamdullah Suphi ülkedeki komünist fırkaların taraftarlarının yalnız işçiler olmayıp özellikle üniversite ve diğer yüksek okul öğrencilerinden oluştuğuna dikkat çekildiğini, bu durum

\footnotetext{
${ }^{14}$ Başbakanlık Cumhuriyet Arşivi, 0301024666717, s.2.

${ }^{15}$ Başbakanlık Cumhuriyet Arşivi, 0301024666717, s.3.
} 
karşısında hükümetin gençleri sükunete ve Romanya'nın geleceği için ilimle uğraşmaya davet ettiğini vurgulamaktadır ${ }^{16}$.

Ancak Hamdullah Suphi, beyannamenin ilk cümlesinde yer alan Romanya'yı büyük bir tehlike tehdit ediyor fikrinin içeride ve dişarıda korkunç bir tesir yarattığına dikkat çekerken hükümetin bu denli endişelenmesinin yerinde olup olmadığını, alınan örfi idarenin arkasında başka sebepler olup olmadı̆̆ını sorgulamaktadır. Bu bağlamda, Başbakan Vaida, Dahiliye Nazırı Mironescu, Ulaştırma Nazırı Mirto ve Emniyet Genel Müdürü General Stingaço ile görüşmüştür. Her ne kadar hükümetin endișelenmesini gerektirecek bir durum olup olmadığ konusunda zihninde soru işaretleri varsa da eski Türk Ocakları başkanı ve Türk milliyetçiliğinin önde gelen isimlerinden olan büyük elçiye göre büyüyen bir Komünizm tehlikesinin "Türk vatanına pek yakın olan bu köşede hakiki mahiyetini tespit etmek elzemdir"17.

Hamdullah Suphi görüştüğü bakanların ortak bir noktaya işaret ettiklerini belirtmekte ve İngiliz hükümetinin Romanya hükümetini işçi hareketinin ortaya çıkmasından çok önce silahlı bir komünist ayaklanması olacağı konusunda haberdar ettiği yönünde bir bilgi aldığını belirtmektedir. Yine bu bilgiye bağlı olarak Dahiliye Nazırı, Berlin Komünist merkezinin Moskova'nın emri ile Romanya'ya işçi ayaklanmasını hazırlamak üzere bazı memurlar gönderdiğini belirtmiştir. Berlin'den gönderilen bazı belgelerin ele geçirildiğine değinen bakan, ülkedeki ayaklanmanın ihtiyatla hazırlandığı ve tam vakti gelmeden önce ortaya çıkmaması konusunda itina edildiğine vurgu yaptıktan sonra buna rağmen, Romanyalı işçilerin dışarıdan gelen teşviklerin etkisi ile ülkede var olan yoksulluk, yevmiye azlığ 1 ve hükümet kuvvetlerinin azlığını fırsat bilerek birden bire harekete geçtiklerini beyan etmiştir. İşçi sınıfının taleplerinin neler olduğu konusunda ise Dahiliye Nazırı, kendi meslekleri ile ilgili olanların dıșında örfi idarenin kaldırılması ve özellikle de feshedilen Komünist teşekküllerin tekrar açılması gibi siyasi içerikli istekler olduğunu vurgulamıştır.

$\mathrm{Bu}$ arada Mecliste bazı milletvekilleri ve ülkede yayın yapan gazeteler hükümeti tehlikeyi vaktinde görememekle suçlarken, Bükreş, Yaş, Kalas, Ploeşti, Arad, Temeşoir, Oradya, Orahova, Dimboviça eyaletlerinde kısa sürede örfi idare oluşturulmuştur. Hamdullah Suphi, Dahiliye Nazırının dikkat çektiği noktalardan birinin örfi idare kapsamında gerçekleștirilen tutuklamalarda gençlerin aşırı atılgan, şiddet yanlısı faaliyetleri olduğunu belirtmektedir. Bu bağlamda, Komünist görüşe sahip olduğu için sorgulanan gençlerin sadece görüşlerini müdafaa etmekle yetinmedikleri aynı zamanda istenirse bunları yazıp imzalayacaklarını söyleyecek kadar cesaretli oldukları da Türk Büyük Elçisinin yapmış olduğu görüşmeler sonunda elde ettiği bilgiler arasındandır. Bu açıklamaların Romanya hükümetinin komünizm

\footnotetext{
${ }^{16}$ Başbakanlik Cumhuriyet Arşivi, 0301024666717, s.4.

${ }^{17}$ Başbakanlık Cumhuriyet Arşivi, 0301024666717, s.4
} 
tehlikesi karşısında ülke gençliğini özellikle dikkat edilmesi gereken bir unsur olarak değerlendirmesini haklı çıkarmaktadır denilebilir.

Bu arada, Hamdullah Suphi de Türkiye'de komünizmle mücadelede polis ve mahkeme takibatının ötesinde belki yine milliyetçi kimliğinin ağır basmasıyla "milliyet ve vatanperverlik hissi, cereyanı komünizm hatalart gizlice söylenerek azami derecede uyandirllmall, takviye olunmalt ve bu fikir, mukabil fikirle ezilmelidir" şeklinde kendi ülkesinde yapılabilecekler konusunda fikirlerini belirtmeyi ihmal etmeyecektir. Bu açıdan yaklaşıldığında Türkiye'de bu yönde ciddi bir kaygı yokken ${ }^{18}$ ve yukarıda da değinildiği gibi ne Romanya'da ne de Avrupa'nın diğer yerlerinde Komünizm etkin bir yere sahip değilken, coğrafi olarak Türkiye'ye yakınlığından hareketle henüz oluşum aşamasında olduğunu belirttiği hareketin varlığı onu kapsamlı bir rapor hazırlamaya sevk etmiştir.

Olayların gelişimi ile ilgili olarak Ulaştırma Nazırı ile yaptığı görüşmeden elde ettiği izlenimlere değinirken olayla ilgili çizilen ciddi portreye rağmen tutuklanan işçiler üzerinde az sayıda silaha rastlanması Hamdullah Suphi'nin dikkatini çekmiştir; yakalanan 2000 kişiye karşın ele geçen silah sayısı sadece 20'dir. Bunun dışında işçilerin aylıkları konusunda ne kadar artırıma gidildiği sorusuna cevaben 1200 Ley'den( yaklaşık 15 TL) 2500 Ley'e yükseltildiği beyan edilmiştir. Bu verilere dayanarak misli bir artış elde eden işçilerin bu hareketinin önceden tertiplenmiş bir hareket olarak değerlendirilemeyeceği kanaatine varmıştır. İlgili bakanın ise konunun dışarıdan gelen tahrikler açısından yaklaşılması gerektiği ve olayın vaktinden önce ortaya çıktığını vurgulaması üzerine Türk Büyük Elçisi Romanya'nın asıl sorunun muzdarip durumdaki halkın itibarını kaybeden idari ve siyasi teşkilat yönetimi altında ümitsiz bir durumda başı boş brrakılmaları olduğu yorumunu yapmaktadır ${ }^{19}$.

İşçi hareketi ile ilgili izlenimlerini bu şekilde rapor eden Hamdullah Suphi, "hususi bir ehemmiyetle arz edeceğim en esasl cihet Romanya'da çok etraflı bir Komünist cereyantn mevcut olduğuna işaret etmektir" dedikten sonra Romanya'da var olan Komünist teşkilatlanmayı en ince ayrıntısına kadar anlatmıştır.

Her şeyden önce işçi hareketi sırasında binlerce işçinin 7-8 merkezde harekete geçmesine rağmen ele geçirilen silah sayısının azlığına bağlı olarak "Romanya'daki Bolşevik cereyanı bir fikir hazırlığı safhasindandır" yorumu ile cümlelerine başlayan Hamdullah Suphi'ye göre Berlin'den gönderilen ve Romanya hükümetinin eline geçen talimatta şiddetli hareketlerden kaçınılması yönünde tavsiyelerin olmasının Romanya'daki Komünist hareketi dışarıdan kontrol eden merkezlerin henüz bu oluşumun silahlı bir isyan için olgun hale gelmediğine inandıklarını göstermektedir.

${ }^{18}$ Türkiye'deki sol hareket ile ilgili olarak bkz. Mete Tunçay, Türkiye'de Sol Akımlar, c.II, BDS yay., 1992; Mustafa Yılmaz,"Komünizm Karşısında Atatürk”, Erol Güngör'e Armağan-Türk Kültürü Araştırmaları, Ankara, 1998, s.143-157.

${ }^{19}$ Başbakanlık Cumhuriyet Arşivi, 0301024666717, s.9. 
Bundan sonra "Türkiye Cumhuriyet'inin Romanya'da Komünist fikir hazırlı̆̆ı nasıl cereyan ettiğini, istihkak ettiği müstesna ehemmiyete göre takip edebilmesi ve görebilmesi için Emniyeti Umumiye Müdürü General Stingaço'nun adetlerini 200 raddesinde olmak üzere tespit ettiği Bolşevik teşkilattan en mühimlerini vüsukuna mutlak surette kani olabileceğiniz gayet esasl t tahkikata istinaden birer birer arz ediyorum" diyerek Komünist Hareketi başlığı altında henüz fikir hazırlığı safhasında olduğunu belirttiği ancak önemli olduğuna inandığı Romanya'daki Komünist oluşum hakkında bilgi vermeye başlamıştır ${ }^{20}$.

Hamdullah Suphi, Romanya Komünist Fırkası'nın 1918 yılında Rus ihtilalinin etkisi altında Sosyalist Fırkanın ikiye bölünmesi ile ortaya çıktığını belirttikten sonra, 1921 yılında 3 . Enternasyonale dahil olduğuna ve 1932 yılında da Moskova'da 5. Kongresini topladığına işaret etmektedir. Ayrıca, ülke içindeki teşkilat telkin vazifesi görmekte olup ve halkı ihtilal prensiplerine göre yetiştirmeye gayret gösterdiğine de vurgu yapmaktadır.

Ülke içindeki teşkilatlardan Birlik Sendikaları (Syndicats Unitaires) 1923 yılında kurulmus olup Uluslararası Kızıl Sendikalar (International Syndical Rouge) teşkilatına katılmıştır. Hamdullah Suphi, 1929 yılında Temişoara isyanı sebebiyle fesih kararı olsa da gizli biçimde çalışmalarına devam eden bu sendikaların görevlerini; grevlerin ve sokak nümayişlerinin organizasyonunu yapmak, ilan dağıtmak ve Sosyal Demokrat Sendikaları dahilinde kızıl muhalefet oluşumunu sağlamak şeklinde açıklamaktadır. Bunun dışında Romanya hükümetinin ayrı bir önem verdiği ülke gençliğine yönelik olarak Komünist Gençlik Birliği’nden bahseden Türk Büyük Elçisi, Uluslararası Comsomol teşkilatına dahil olan bu teşkilatın Komünist teşkilat için kadroları oluşturacak gençleri yetiştirdiğini belirtmektedir. Amele Köylü Birliği (Le Bloc Ouvrier Paysan) ise seçim dönemi oluşturulan bir oluşum iken elde edilen sonuçların cesaret vermesi ile süreklilik kazanmış olup işçi ve çiftçiler arasında ihtilal fikirlerinin yayılması görevini üstlenen bir teşkilattır.

Tutuklu bulunan Komünistlere maddi manevi ve adli yardım ve hapishanelerde komünist propaganda yapmak ve çeşitli ülkelerin sınırlarından komünist ajanların geçmesini temin amacıyla oluşturulan Kızıl Yardım Cemiyeti (Le Aide Rouge) 1924 yılında Kızıl Yardım Mopr Cemiyetinin bir şubesi olarak ortaya çıkmıștır. Rumen Ameleye Yardım Cemiyeti (L'Aidde Ovriére Roumanie)'nin merkezi Berlin'dedir ve II. Enternasyonal tarafından kurulmuş olan I.A.H. teşkilatının (Internationale Arbeiter Hilfe) bir şubesi olan bu cemiyetin amacı ilga olan sendikalar yerine müstakil sendikalar şeklinde işçi teşkilatı oluşturup, bütün iktisadi sorunlarda işçiyi savunmaktır. Yine benzer bir görevle yükümlü olan Amele Tesanüdü, Rumen Amele Yardım Cemiyeti faaliyetinin takibi ile görevli olup hükmü şahsiyeti olan bir teşkilattır ${ }^{21}$. Kadınlar ve çocuklar için daha iyi

\footnotetext{
${ }^{20}$ Başbakanlık Cumhuriyet Arşivi, 0301024666717, s.11.

${ }^{21}$ Başbakanlık Cumhuriyet Arşivi, 0301024666717, s.13.
} 
bir rejimi savunan ve mahkum komünistlerin ailelerine yardım etmek amacını taşıyan Kadın Komünist Mahfeli (Le Cercle Feminin Communiste)'nin kuruluşu 1922 yılıdır. Yine mahkumlara yardım amacıyla oluşturulan bir organizasyon olarak Hukuki Büro, mahkum Komünistlere avukatlık yapmak, Komünist gazetelerde makaleler yazmak gibi faaliyetlerde bulunmaktaydi ${ }^{22}$.

Türk Büyük Elçisinin yukarıda görev ve amaçlarını belirttiği organizasyonlar dışında Romanya'daki "Komünist hareketi için çok mühim bir ihdas"olarak belirttiği İctimai Irşat ve Tevsik Mahfeli'nden bahsetmektedir. Bu oluşum önemli miktarda avukat, doktor, yazar gibi genç fikir adamı arasında Komünist fikirlerin yayılması görevini üstlenmiştir. Hamdullah Suphi, Romanya'nın iç düzenine karşı ciddi bir tehlike teșkil eden bu organizasyonun faaliyetini şu şekilde ifadelendirmektedir: "konferanslar, tetkikat, içtimai, iktisadi mesaili Marksizm ve Leninizm menşurları arasında nazarı müşahadeye alıp münakaşa etmektir"23.

Romanya'daki Komünist teşkilatlanmayı anlatmaya devamla Hamdullah Suphi, NIM Komünist Teşkilatı başlığı altında Hukuki Beşer İttihadı ve Harp Aleyhine Çalışma Komitesine yer vermektedir. Bu teşkilatlardan ilkinin 1898 tarihinde insani amaçlarla Paris'te kurulmasını 1923 yılında Romanya'da kurulması takip etmiştir. Zaman içinde Komünist unsurlar bu oluşum içine girmeyi başarmışlardır. İkinci oluşum savaş ve askerlik aleyhtarı bir oluşum olmakla kalmayıp aynı zamanda Sovyetler Birliği aleyhine açılacak bir savaşta emperyalist devletlere karşı da mücadeleyi savunup telkin etmektedir.

Bu şekilde Romanya'daki Komünist teşkilatların adları ve amaçlarını belirttikten sonra "Komünist Teşkilatı Neden İbarettir" başlı̆̆1 altında propaganda faaliyetleri, teşkilatçı faaliyet, sokak nümayişleri, siyasi ve askeri casusluk konularına değinen Romanya Türk Büyük Elçisi Hamdullah Suphi, özellikle ne tür propagandalar yapıldığı ile ilgili olarak bilgi vermektedir. Bu bağlamda, konu ile ilgili yayın yapılan evlerde toplantılar yapmak veya şifahi telkin yoluyla propaganda yapmak, gizli olarak ülkeye sokulan gazeteler dahil olmak üzere ülke içinde basılan broşür, gazete, bülten, talimatname ve ilanlarla Komünizm telkininde bulunmak ve bunun dışında kültür ve spor cemiyetlerinin arkasına gizlenerek Komünist faaliyetlerini yürütmek ve Sovyet Rusya hesabına yapılan casusluk faaliyetleri Romanya Komünist Teşkilatının faaliyetleri arasında yer almaktadır ${ }^{24}$. Ayrica, her hangi bir ihtilal veya suikast durumunda kullanılmak üzere ülkenin değişik yerlerinde gizli depolar oluşturulmuştur. Birkaç sene önce bu gibi depoların tespit edildiğini belirten Hamdullah Suphi bu tür depoların oluşumunun Beserabya'da imkan dahilinde olduğunu belirtmektedir. Gizli depolarda bulunan silahların kullanım alanlarından

\footnotetext{
${ }^{22}$ Başbakanlik Cumhuriyet Arşivi, 0301024666717, s.14.

${ }^{23}$ Basbakanlik Cumhuriyet Arsivi, 0301024666717, s.14.

${ }^{24}$ Başbakanlık Cumhuriyet Arşivi, 0301024666717, s.16.
} 
birisi olarak belirtilen suikastlar özellikle "çoğu insan nakleden trenleri yoldan çıkarmak, demiryollarına ve köprülere karşı yakın mazide istimal edilmiştir" dedikten sonra hükümet mensuplarının da bu suikast programının doğrudan hedefi konumunda olduğunun altını çizmektedir.

Ayrıca, Komünistlerce önemli kabul edilen olayların tarihlerinin unutulmaması için uluslar arası komünist bayramlarının kutlanmasının da Komünist faaliyetler arasında önemli bir yere sahip olduğunu belirten Hamdullah Suphi, bundan sonra Komünistlerin Faaliyet gösterdikleri alanlara değinmektedir. Bu çerçevede, Türk Büyük elçisinin raporunda Romanya'da kadın ve erkek iş̧̧ilerin çalıştı̆̆ özel teşebbüsler ve devlete ait sınai kuruluşları, çiftçiler, işsizler, ordu mensupları, okullar, yüksek okul öğrencileri, şimendifer fabrikaları, Sosyal Demokratlara ait meslek sendikaları ve memurlar Komünist teşkilatın hedefleri olarak belirtilmektedir. Yukarıda yer verilen bu hedefler arasında Yahudilerin kurmuş olduğu tüm kültür, spor ve güzel sanatlarla ilgili cemiyetler ve azınlıklara ait organizasyonlar da ayrı bir yere sahiptir ${ }^{25}$. Sonuç olarak, Komünist teşkilatların her alanda özellikle de köylü halk arasına sokulmaya çalıştığının altını çizen Hamdullah Suphi, Bulgaristan ve Yunanistan'da zaman zaman görülen Komünist teşkilatın Romanya'da "büyük ihtilal için istihzaratını" yapmakta olduğunu dile getirmekte ve sözlerine şu şekilde devam etmektedir: "pek yakın ati için bir şey söylenemezse de Komünizmin en tabii müșterisi mahrum ve muzdarip kütleler olduğu için Romanya'da hakikaten fazla müsamaha edilmiş olan Komünist teşkilatının örfi idare dolayısıla feshedilmiş olmalarına rağmen böyle muzdarip bir muhit varken faaliyetlerinden sarfi nazar edeceklerine ihtimal verilemez" ${ }^{26}$.

Türkiye Büyük Elçisi, Romanya Emniyet kuvvetlerinin 1srarlı takipleri sonucu müdahale edilen Komünist teşkilatın hemen yer ve isim değişikliğine gittiğini, tutuklananların yerine hemen başkalarının getirildiğini ve bu şekilde faaliyetine devam ettiklerini vurguladıktan sonra ülkede yakın zamanda ortaya çıkan işçi isyanı ile ilgili "Romanya'da yalnız fikri istihzar devrinde olan Komünist cereyanının bazı müfrit müminleri tarafindan vaktinden evvel ihdas edilmiş bir hadise" tanımını yapmaktadır.

Bu şekilde, Romanya'da 1930'lu yılların başında ülkedeki siyasi durum çerçevesinde Komünizmin durumunu değerlendiren Türk Büyük Elçisi her ne kadar Komünist hareketin henüz fikri hazırlık aşamasında olduğunu beyan etse de, raporunun içerdiği bilgilerden yola çıkarak, Romanya'daki Komünist hareketin iyi tanzim edilen ayrıntılı bir programa sahip olduğunu vurgulayarak raporuna son vermektedir.

Hamdullah Suphi'nin yukarıda detayları ele alınan bu raporu sonrasında Romanya'da nasıl bir siyasi gelişim seyri yaşandığına genel hatlarıyla değinmek konu bütünlügüu açısından gereklidir.

\footnotetext{
${ }^{25}$ Başbakanlık Cumhuriyet Arșivi, 0301024666717, s.19.

${ }^{26}$ Başbakanlık Cumhuriyet Arşivi, 0301024666717, s.20.
} 
Bu bağlamda, 1933 yılı Ocak ayında Almanya'da Nazilerin iktidara geliși ve Versay antlaşmasını hiçe sayması ile toprak taleplerinin gündeme gelmesi diğer revizyonist ülkelerden Macaristan'1 da cesaretlendirmiştir. Bu noktada Romanya Avrupa'da güçlü güvenlik sistemi yaratılması için harekete geçecektir. Var olan antlaşmaların varlığının devamı ve yeni savunma anlaşmalarına imza atmak ve Milletler Cemiyetinin rolünü güçlendirmek gerektiğine inanmaktadır. Bu inanç doğrultusunda Dıș İşleri Bakanlığ1 süresince(1932-1936) Nikolae Titulescu ülkesi adına ciddi bir misyon üstlenecektir.

Yine 1933 Şubat'inda Çekoslovakya ve Yugoslavya ile anti-revizyonist yapıyı güçlendirme amacıyla Küçük Antanta imza atan Romanya, bir yıl sonra 1934 Şubat'ında Balkan Antantını imzalayacaktır.1933 yılı ortalarında hazırlanmasında bizzat Titulescu'nun emeği geçen Londra Konvensiyonuna da imza atmış olan Romanya revizyonist siyasete karşı oluşturulan her türlü organizasyona dahil olmaya çalışmıştır. Bu bağlamda, ikili ilişkiler açısından da özellikle dikkatli davranan Romanya, Sovyetler Birliği ile diplomatik ilişkileri geliştirmeye çalıșmıștır. 1934 yılı ortalarında ilk adımı atılan bu girişim 1936 yılında Beserabya'nın Romanya ile birleşmesini sağlayacak olan saldırmazlık paktı ile noktalanacakken Rus Dışişleri Bakanını Litvinov'un paktı imzalama aşamasında erteleme talebi ile başarılı olunamamıştır.

Aynı süreçte, 1935 yılında İtalya Habeşistan'a saldırırken, 1936'da Rhineland Almanya tarafından işgal edilecektir. Bu gelişmeler karşısında Kral II. Carol, Sovyetlerle bir pakt imzalamaktansa Almanya ile yakınlık kurmayı tercih edecektir. Bu arada 1936 yılında Kral ile Romanya-Sovyet ilişkilerini geliştirme noktasında ters düşen Titulescu, görevden çekilmek zorunda kalacaktır. Bu gelişme sonrasında ise Sovyet Dışişleri Bakanı Litvinov saldırmazlık paktının tarihe karıştığına vurgu yapmayı ihmal etmeyecektir.

1938 yılı ise Avrupa'da savaş çanlarının çalmaya başladığı yıl olacaktır. Almanya'nın Mart ayında Avusturya'yı ilhakını Eylül'de Südetlerin ele geçirilmesi izleyecektir. Ekim ayında Polonya Dışişleri Bakanının Kral II. Carol'a Çekoslovakya'nın Romen ve Polonyalıların yaşadığı sınır bölgelerini aralarında paylaşma teklifine Kral, olumsuz cevap verecektir. Bu açıdan bakıldığında Çekoslovakya'nın parçalanması aslında Romen dış politikası için ciddi bir darbe olacaktır. Bu olay, revizyonizm karşısında Romanya'nın büyük önem atfettiği Küçük Antant'ın sonu anlamına gelmektedir. Bu ortamda Romanya'nın önemli müttefiklerinden Polonya'nın Almanya'ya yaklaşması statükonun korunması ihtimalini zayıflatan bir başka gelişme olmuştur. Sonuçta, Kralın da bizzat girişimleriyle Almanya ile ekonomik ilişkileri geliştirme arzusu 1939 Mart ayında Romanya sınırlarına dayanan Alman ordusunun baskısıyla ağır bir ekonomik anlaşma ile noktalanır. Ancak, Balkanlarda dengeyi sağlamaya çalışan İngiltere ve 
Fransa'nın da Romanya ile ekonomik anlaşmalar yapmasını 1939 yılında tek taraflı olarak Yunanistan ve Romanya'ya verilen siyasi garanti izleyecektir ${ }^{27}$.

Yine 1939 yazında Romen kamuoyu İngiliz-Fransız-Sovyet siyasi ve askeri görüşmelerinin başarı ile noktalanacağını beklerken aynı süreçte Türkiye'nin aracılığı ile Romanya, Sovyetlerle karşılıklı saldırmazlık paktı imzalamak için bir diplomasi yürütmekteydi. Ancak bu başarısızlıkla sonuçlanacak ve kısa bir süre sonra 1Eylül 1939'da Alman ordularının Polonya'ya batıdan ve bunu takiben Sovyet ordularının da doğudan girmesi ile II. Dünya Savaşı başlayacaktır.

Savaş sırasında Almanya'nın yanında yer alan Romanya'nın kaderini Ekim 1944 tarihinde İngiltere Başbakanı Churcill ile Stalin arasında Moskova'da gerçekleştirilen görüşme belirleyecektir. Nüfuz bölgelerinin tespit edildiği bu görüşmede Romanya, Sovyet nüfuz sahasına bırakılacaktır $^{28}$. Savaşın sonunda ise Sovyet işgali altında bir Romanya vardır. 10 Şubat 1947 tarihinde yapılan barış antlaşması ile Beserabya ve Bukovina Sovyetler Birliği'ne, Dobruca'nın güneyi Bulgaristan'a, Transilvanya'nın bir kısmı da Macaristan'a bırakılmıştır.

Uluslararası ortamda savaş sonunda toprak kaybeden Romanya'da her şeye rağmen galip gelen bir güç vardır. Bu güç Komünizm olacaktır. 1947'de Kral tahtından feragat edecek ve Romanya bir Halk Cumhuriyeti olacaktır. 1948 yılından itibaren de İşçi Partisi ülkeyi Sovyet sosyalizmini örnek alarak idare edecek ve ismini Romanya Komünist Partisi olarak değiştirecektir ${ }^{29}$. Ayrıca Romanya 1949 yılında COMECON ve 1955 yılında Varşova Paktının kurucu üyeleri arasında yer alarak 1989'larda sarsılmaya başlayacak olan Demir perde gerisindeki yerini alacaktır.

\section{SONUÇ}

Bu şekilde anılan dönemde henüz Avrupa'da etkin bir varlık göstermese de, 1930'larda Romanya hükümetinin bir tehdit olarak algıladığı Komünist örgütlenme o dönem Türkiye Büyük Elçisi olarak Romanya'da bulunan, bir zamanlar Türk Ocakları başkanlığı yapmış ve Türk milliyetçiliğinin önemli isimlerinden Hamdullah Suphi'nin de dikkatini çekmiş ve Türkiye'ye coğrafi olarak yakın bir yerde bu tür bir oluşumun varlığı onu konu ile ilgili detaylı bir rapor hazırlamaya sevk etmiştir.

He ne kadar o dönem için Romanya'daki Komünist hareket Türk Büyük Elçisi tarafından henüz fikri hazırlık aşaması içindeki bir oluşum olarak değerlendirilse de, hazırlık aşamasındaki hareketin iyi tanzim edilen ayrıntılı bir programa sahip olması onda geleceğe dönük olarak ciddi bir endişe uyandırmıştır. Bu bağlamda, Türk Büyükelçisinin deyimiyle "pek yakın ati için bir şey söylenemezse de Komünizmin en tabii müşterisi mahrum ve

${ }^{27}$ Treptow, a.g.e., ss. 459-464.

${ }^{28}$ Treptow, a.g.e., s.480; Ferhat Başdoğan, "Romanya ve Türk Romen İlişkileri", Stratejik Etütler Bülteni, yıl:26,sa.87, s. 33

${ }^{29}$ Başdoğan, a.g.m. 1992, s.33 
muzdarip kütleler olduğu için" Romanya Komünizmin vazgeçilmez hedefidir. Sonuçta, II. Dünya Savaşı sonunda merkezi ve güneydoğu Avrupa'da ortaya çıkan manzara Türk Büyük elçisinin 1933 yılında kaleme aldığı raporundaki tespitlerinin doğruluğunu ortaya koymuştur denilebilir.

\section{KAYNAKLAR}

\section{Arşiv Belgeleri}

Başbakanlık Cumhuriyet Arşivi, Hariciye Vekaleti, 030.10.246.667.17.

Başbakanlık Cumhuriyet Arşivi, Hariciye Vekaleti 030.10.246.666.30.

\section{Kitap ve Makaleler}

Anzerlioğlu, Yonca, (2006), "Bükreş Büyükelçisi Hamdullah Suphi ve Gagauz Türkleri”, Bilig, Güz.

Armaoğlu, Fahir, (t.y.), 20. Yüzyll Siyasi Tarihi, İstanbul.

Başdoğan, Ferhat, (1992), "Romanya ve Türk Romen İlişkileri”, Stratejik Etütler Bülteni, yıl:26,sa.87.

Dağıstan, Adil, (2002) "Hamdullah Suphi'nin Romanya Büyükelçiliği ve Gagauz Türkleri”, Atatürk Araştırma Merkezi Dergisi, c.XVIII, Kasım, sa.54.

Fisher, Stephan -Galati, (1970), Twentieth Century Romania, New York.

Gilberg, Trond, (1990), Nationalism and Communism in Romania, The Rise and Fall of Ceausescu's Personal Dictatorship, Oxford.

Guboğlu, Mihail, (1983), “Atatürk'ün Cumhurbaşkanlığı Döneminden II. Dünya Savaş1'na Kadar Türk-Romen İlişkileri(1923-1944)”, Belleten, C.XLVII, sa.188, Ekim.

Kemal Karpat, (2004), Balkanlar'da Osmanlı Mirası ve Ulusçuluk, Ankara.

Kollu, Atilla, (1996), Türkiye-Balkan İlişkileri, H.Ü. Atatürk İlkeleri ve İnkılap Tarihi Enstitüsü Yayınlanmamış Doktora Tezi, Ankara.

Tevetoğlu, Fethi, (1986), Hamdullah Suphi Tanriöver, Ankara.

Treptow, Kurt (ed.), (1996), A History of Romania, Iasi.

Tunçay, Mete, (1992), Türkiye'de Sol Akımlar, c.II, BDS yay.

Watts, Larry L., (1993), Romanian Cassandra:Ion Antonescu and The Struggle for the Reform,1916-41, Boulder:East European Monographs.

Yılmaz, Mustafa, (1998), "Komünizm Karşısında Atatürk”, Erol Güngör'e Armağan-Türk Kültürü Araştırmaları, Ankara. 